\title{
Effect of drying period of harvested plant and method of threshing on yield and quality of kenaf seed
}

\author{
A. F. Mollah', M. A. Khan ${ }^{b}$, M. Z. Tareq ${ }^{\mathrm{c}}$, A. B. M. Z. Hoque ${ }^{\mathrm{d}}$ and M. R. Debnath ${ }^{\mathrm{e}}$ \\ aJute Research Regional Station, Bangladesh Jute Researrch Institute (BJRI), Rangpur \\ bFarm Management Unit, BJRI, Dhaka \\ 'BARJ-Project, JAES, BJRI, Manikganj \\ dGenetic Resource \& Seed Division, BJRI, Dhaka \\ eJute Research Regional Station, BJRI, Faridpur, Bangladesh
}

$\bowtie$ For any information: ask.author@journalbinet.com, Available online: 25 December 2016.

\begin{abstract}
An experiment was conducted at the Bangladesh Jute Research Institute (BJRI), Regional Station, Rangpur, Bangladesh during July to December, 2014 and 2015 to study the effect of drying period of harvested plant and method of threshing on yield and quality of kenaf seed. The trial used three drying period of harvested plant (viz., threshing without drying of harvested plant, threshing after 7 days drying of harvested plant, threshing after 14 days drying of harvested plant) and two method of threshing (viz., Traditional method of threshing, mechanical method of threshing) in a Randomized Complete Block Design (RCBD) with four replications. The highest kenaf seed yield was obtained at 7 days drying period and from mechanical method (788.03 $\mathrm{kgha}^{-1}$ ) with minimum requirement of time. Seed quality was found better at no drying of harvested plants in both the threshing methods.
\end{abstract}

Key Words: Drying period, Threshing method, Yield, Quality and Kenaf seed

Cite article: Mollah, A. F., Khan, M. A., Tareq, M. Z., Hoque, A. B. M. Z. and Debnath, M. R. (2016). Effect of drying period of harvested plant and method of threshing on yield and quality of kenaf seed. Journal of Bioscience and Agriculture Research, 11(02), 963-967.

Article distributed under terms of a Creative Common Attribution 4.0 International License.

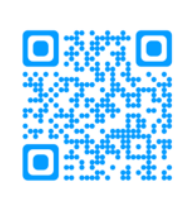

\section{Introduction}

Kenaf is a commercially important fiber crop next to cotton and jute. Both jute and kenaf constitute raw jute as it goes in trade and industry. Kenaf accounts for about 10 percent of total raw jute production in Bangladesh (Deb and Bairagi, 2008). In Bangladesh around 0.04 million hectares of land is now devoted to kenaf cultivation producing 0.08-0.09 tons per annum with an average yields of 2.02.5 tonsha $^{-1}$ (Mostofa, 2012). The expansion of kenaf cultivation in Bangladesh has been limited by shortage of quality seed. Very few amounts of kenaf seed are produced in Bangladesh, but there is no 
statistics about kenaf seed production (Khan et al., 2014). In adequate supply of quality seed is the major barrier to the expansion of kenaf. The quality of kenaf seeds depends on many pre and post harvest factors, such as time of cultivation and method, time of seed maturity and harvest, threshing, processing, and drying operation and storage condition. Mechanical damage is one of the major factors which reduce the seed quality. In traditional method, some amount of kenaf seed losses due to inefficient harvesting and threshing practices. Manual threshing methods are labour intensive as compared to mechanical threshing. However, harvest of kenaf seed is another major problem as bristles from kenaf capsules can cause extreme itchiness and irritation to human skin and farmers face an acute problem of threshing kenaf seed. The seed injuries are caused from the weathering, fungi, insects, artificial drying and mechanical damage during harvest, handling, threshing and storage (Henning et al., 2006). From the above facts the experiment was designed to develop economically feasibility kenaf seed threshing technique for getting more seed yield and quality.

\section{Materials and Methods}

An experiment was conducted at the Bangladesh Jute Research Institute (BJRI), Regional Station, Rangpur, Bangladesh during July to December 2014 and 2015 to the see the effect of drying period of harvested plant and method of threshing on yield and quality of kenaf seed. The experiment comprised three drying period of harvested plant (viz., threshing without drying of harvested plant, threshing after 7 days drying of harvested plant and threshing after 14 days drying of harvested plant) and two method of threshing (viz., Traditional method of threshing and mechanical method of threshing) in a Randomized Complete Block Design (RCBD) with four replications. The unit plot size was $8 \mathrm{~m} \times 5 \mathrm{~m}$. Kenaf variety HC-95 was used as test crop. The experimental plots were fertilized with urea, triple super phosphate (TSP), murate of potash (MoP) and gypsum @ 180-50-20-50 kg ha-1, respectively. All fertilizers except urea were applied during final land preparation. Urea was top dressed in three equal splits at 15, 30 and 45 days after sowing (DAS). The seed was sown @ $12 \mathrm{~kg} \mathrm{ha}^{-1}$ on 25 August in 2015 in line sowing. Weeding was done by hand at 30 days after sowing (DAS). Thinning was done to maintain plant to plant distances of about $15 \mathrm{~cm}$ along with the weeding operation. The crop was infested by mealy bug and white fly at the vegetative stage which were successfully controlled by spraying Ripcord $10 \mathrm{EC} @ 2 \mathrm{mlL}^{-1}$ of water for two times at an interval of 10 days. Insecticide was applied at 30 days after sowing. No irrigation was needed while drainage of excess water was done as and when necessary.

Crop was hand harvested at maturity (i.e. when $80 \%$ of the capsules become brown in color). Drying period of harvested plant and threshing was done as per experimental specification. Paddy thresher machine was use as mechanical threshing. Initial seed moisture content was measure at threshing time. Then seeds were sun dried on jute mat kept on cemented floor for 5-6 days to around 8\% moisture content. After cleaning the seed was stored in thick polythene bags and kept in the laboratory until further use for quality tests. Standard laboratory germination accelerated ageing test and field emergence percentages were done to record on germination and vigour of seed. A brief description on different laboratory tests is given below.

Laboratory germination test: Test was conducted on top of the paper method. The germination percentage of seed was measured using the following formula:

Germination $(\%)=\begin{gathered}\text { Number of normal seedling } \\ \text { Number of seed sown }\end{gathered} \quad \times 100$

Accelerated ageing (AA) test: $15 \mathrm{~g}$ seed in accelerated ageing chamber exposing to $41^{\circ} \mathrm{C}$ temperature and $100 \%$ RH for 72 hours. Following the laboratory germination test (ISTA, 1999).

Statistical analysis of data: The collected data on different yield related characters and seed quality parameters were subjected statistical analysis following ANOVA technique. Differences among treatment means were adjusted by Duncan's Multiple Range Test with the help of a computer based statistical package program MSTAT-C (Gomez and Gomez, 1984). 


\section{Results and Discussion}

\section{Effect of drying period of harvested plant}

Almost all the parameters were not found statistically significant in terms drying period of harvested plant (Table $01 \&$ Table 02). Significantly the highest seed moisture content (20.48\%) was obtained from the threshing without drying of harvested plant and lowest (14.52\%) in threshing after 14 days drying of harvested plant (Table 01). The present study revealed that total unfilled and cracked seed (6\%) was found in threshing after 14 days drying of harvested plant and lowest (5.25\%) in threshing after 7 days drying of harvested plant (Table 01). Best seed quality was obtained in threshing without drying of harvested plant. Significantly the highest germination (88\%), accelerated ageing germination $(71 \%)$ and field emergence $(83.44 \%)$ were found in threshing without drying of harvested plant and lowest in threshing after 14 days drying of harvested plant (Table 02).

\section{Effect of method of threshing}

Significantly the highest seed obtained from mechanical threshing (764.4 $\left.\mathrm{kgha}^{-1}\right)$ with lowest time required (13.61man days/ha) than traditional method of harvesting (Table 01). The present study revealed that the highest total unfilled and cracked seed (6.71\%) was found in mechanical method of threshing (Table 01). There was no significant difference of seed quality between in mechanical and traditional method of threshing (Table 02). Similar report was recorded by Vishwanatha (2005) in maize, Lee Sun Ho et al. (1998) in sesame, Kammar and Batagurki (2001) in finger millet and many other scientists.

\section{Interaction effect of drying period and method of threshing}

Significantly the highest seed obtained from mechanical threshing method with lowest time required in all the drying period than the harvesting of traditional method (Table 03). Seed moisture content (20.65\% and $20.31 \%)$ was obtained in highest from the threshing without drying of harvested plant in both the threshing method and the lowest (14.49\% and $14.54 \%$ ) in threshing after 14 days drying of harvested plant in both the threshing method. Significantly the highest total unfilled and cracked seed was found in mechanical method of threshing in all the drying period (Table 03). Significantly the highest accelerated ageing germination and field emergence was found in threshing without drying of harvested plant in both the threshing method (Table 04). Similar result was recorded by Jha et al. (1996) in soybean, Khan et al. (1997) in rice and Dauda and Aviara (2001) in maize.

Table 01. Effect of drying period and method of threshing on seed moisture content, total unfilled and cracked seed, time required for threshing and seed yield from kenaf seed threshing

\begin{tabular}{|c|c|c|c|c|c|c|c|c|c|c|c|c|}
\hline \multirow[t]{2}{*}{ Trea } & \multicolumn{3}{|c|}{ Seed moisture \% } & \multicolumn{3}{|c|}{$\begin{array}{l}\text { Total unfilled and } \\
\text { cracked seed (\%) }\end{array}$} & \multicolumn{3}{|c|}{$\begin{array}{c}\text { Time required for } \\
\text { threshing } \\
\text { (Man-days/ha) }\end{array}$} & \multicolumn{3}{|c|}{ Seed obtained kgha ${ }^{-1}$} \\
\hline & 2014 & 2015 & Pooled & 2014 & 2015 & Pooled & 2014 & 2015 & Pooled & 2014 & 2015 & Pooled \\
\hline \multicolumn{13}{|c|}{ Drying period } \\
\hline $\mathrm{d}_{0}$ & $20.34 a$ & $20.62 a$ & 20.48 & $5.38 \mathrm{ab}$ & 5.63 & 5.51 & 18.44 & 16.62 & 17.53 & $591.30 c$ & $705.50 \mathrm{~b}$ & 648.4 \\
\hline $\mathrm{d}_{1}$ & $17.14 \mathrm{~b}$ & $16.94 b$ & 17.04 & $5.25 b$ & 5.25 & 5.25 & 18.60 & 15.57 & 17.09 & $663.8 \mathrm{a}$ & 718.98ab & 691.39 \\
\hline $\mathrm{d}_{2}$ & $14.86 \mathrm{c}$ & $14.17 \mathrm{c}$ & 14.52 & $6.25 a$ & 5.75 & 6.00 & 18.69 & 15.67 & 17.18 & $628.90 \mathrm{~b}$ & $735.55 a$ & 682.23 \\
\hline$S \bar{x}$ & 0.31 & 0.21 & - & 0.30 & 0.23 & - & 0.67 & 0.43 & - & 25.11 & 9.03 & - \\
\hline C.V. (\%) & 5.07 & 3.47 & - & 15.31 & 11.69 & - & 10.15 & 7.65 & - & 11.31 & 3.55 & - \\
\hline L. of sig. & $* *$ & ** & - & $* * *$ & $N S$ & - & $N S$ & $N S$ & - & $* * *$ & * & - \\
\hline \multicolumn{13}{|c|}{ Threshing method } \\
\hline $\mathrm{M}_{\mathrm{t}}$ & 20.62 & 17.33 & 18.98 & 4.42 & 4.50 & 4.46 & 21.85 & 19.99 & 20.92 & 534.55 & 631.98 & 583.27 \\
\hline $\mathrm{M}_{\mathrm{m}}$ & 20.06 & 17.15 & 18.61 & 6.83 & 6.58 & 6.71 & 15.31 & 11.91 & 13.61 & 721.45 & 808.03 & 764.4 \\
\hline$S \bar{x}$ & 0.31 & 0.21 & - & 0.30 & 0.23 & - & 0.67 & 0.43 & - & 25.11 & 9.03 & - \\
\hline C.V. (\%) & 5.07 & 3.47 & - & 15.31 & 11.69 & - & 10.15 & 7.65 & - & 11.31 & 3.55 & - \\
\hline L. Sig. & $* *$ & ** & - & $* * *$ & * & - & $* * *$ & * & - & $* * *$ & $*$ & - \\
\hline
\end{tabular}


Table 02. Seed germination (\%), accelerated ageing germination (\%) and field emergence (\%) of kenaf seed as influenced by drying period and method of threshing

\begin{tabular}{|c|c|c|c|c|c|c|c|c|c|}
\hline \multirow[t]{2}{*}{$\begin{array}{c}\text { Drying } \\
\text { period(days) }\end{array}$} & \multicolumn{3}{|c|}{ Germination (\%) } & \multicolumn{3}{|c|}{$\begin{array}{l}\text { Accelerated ageing } \\
\text { germination }(\%)\end{array}$} & \multicolumn{3}{|c|}{ Field emergence (\%) } \\
\hline & 2014 & 2015 & Pooled & 2014 & 2015 & Pooled & 2014 & 2015 & Pooled \\
\hline $\mathrm{D}_{0}$ & 86.13 & 89.88a & 88.01 & $70.38 a$ & $71.63 a$ & 71 & $83.00 \mathrm{a}$ & $83.88 a$ & 83.44 \\
\hline $\mathrm{D}_{1}$ & 85.38 & $86.63 b$ & 86.01 & 69.50ab & $70.13 \mathrm{ab}$ & 69.82 & 81.38ab & $81.63 b$ & 81.51 \\
\hline $\mathrm{D}_{2}$ & 84.13 & $85.63 b$ & 84.88 & $67.75 \mathrm{~b}$ & $68.63 \mathrm{~b}$ & 68.19 & $80.38 b$ & $80.63 b$ & 80.51 \\
\hline$S \bar{x}$ & 0.78 & 0.85 & - & 0.64 & 0.75 & - & 0.57 & 0.44 & - \\
\hline C.V. (\%) & 2.57 & 2.74 & - & 2.64 & 3.04 & - & 1.99 & 1.52 & - \\
\hline L. Sig. & $N S$ & $* *$ & - & $*$ & $*$ & - & * & $* *$ & - \\
\hline \multicolumn{10}{|c|}{ Threshing method } \\
\hline $\mathrm{M}_{\mathrm{t}}$ & 85.00 & 87.17 & 86.09 & 68.92 & 69.75 & 69.34 & 81.83 & 81.75 & 81.79 \\
\hline $\mathrm{M}_{\mathrm{m}}$ & 85.42 & 87.58 & 86.5 & 69.50 & 70.50 & 70.00 & 81.33 & 82.33 & 81.83 \\
\hline$S \bar{x}$ & 0.78 & 0.85 & - & 0.64 & 0.75 & - & 0.57 & 0.44 & - \\
\hline C.V. (\%) & 2.57 & 2.74 & - & 2.64 & 3.04 & - & 1.99 & 1.52 & - \\
\hline Level of sig. & $N S$ & $N S$ & - & $N S$ & $N S$ & - & $N S$ & $N S$ & - \\
\hline
\end{tabular}

Table 03. Interaction effect of drying period and method of threshing on seed moisture content, total unfilled and cracked seed, time required for threshing and seed yield from kenaf seed threshing

\begin{tabular}{|c|c|c|c|c|c|c|c|c|c|c|c|c|}
\hline \multirow[t]{2}{*}{$\begin{array}{c}\text { Drying period } \\
\times \\
\text { Threshing } \\
\text { method } \\
\end{array}$} & \multicolumn{3}{|c|}{$\begin{array}{c}\text { Seed moisture content } \\
(\%)\end{array}$} & \multicolumn{3}{|c|}{$\begin{array}{l}\text { Total unfilled and } \\
\text { cracked seed (\%) }\end{array}$} & \multicolumn{3}{|c|}{$\begin{array}{c}\text { Time required for } \\
\text { threshing } \\
\text { (Man-days/ha) }\end{array}$} & \multicolumn{3}{|c|}{ Seed obtained kgha-1 } \\
\hline & 2014 & 2015 & Pooled & 2014 & 2015 & Pooled & 2014 & 2015 & Pooled & 2014 & 2015 & Pooled \\
\hline$\overline{D_{0} \times M_{t}}$ & $20.62 a$ & $20.68 a$ & 20.65 & $4.00 \mathrm{c}$ & $4.50 \mathrm{~b}$ & 4.25 & $21.64 \mathrm{a}$ & $21.14 \mathrm{a}$ & 21.39 & $487.8 \mathrm{l}$ & $88.00 \mathrm{c}$ & 537.9 \\
\hline $\mathrm{D}_{0} \times \mathrm{M}_{\mathrm{m}}$ & $20.06 a$ & $20.56 a$ & 20.31 & $6.75 a$ & $6.75 a$ & 6.75 & $15.24 b$ & $1 \mathrm{~b}$ & 13.68 & 694.7 & $3 \angle$ & 58.85 \\
\hline${ }_{1} \times \mathrm{M}_{\mathrm{t}}$ & $17.06 \mathrm{~b}$ & $17.07 \mathrm{~b}$ & 17.07 & $4.00 \mathrm{c}$ & $4.25 \mathrm{~b}$ & 4.13 & $21.88 \mathrm{a}$ & $19.30 \mathrm{a}$ & 20.59 & $558.8 \mathrm{~b}$ & 630.70 & 594.75 \\
\hline $\mathrm{D}_{1} \times \mathrm{M}_{\mathrm{m}}$ & $17.21 b$ & $16.81 b$ & 17.01 & $6.50 \mathrm{ab}$ & $6.25 a$ & 6.38 & $15.33 b$ & $11.83 b$ & 13.58 & $768.8 \mathrm{a}$ & 807 & 788.03 \\
\hline${ }_{2} \times \mathrm{M}_{\mathrm{t}}$ & $14.74 \mathrm{c}$ & $14.24 \mathrm{c}$ & 14.49 & $5.25 \mathrm{bc}$ & $4.75 b$ & 5.00 & $22.03 a$ & $19.53 a$ & 20.78 & $557.0 \mathrm{~b}$ & 677.2 & 617.13 \\
\hline $\mathrm{D}_{2} \times \mathrm{M}_{\mathrm{m}}$ & $14.99 c$ & $14.09 \mathrm{c}$ & 14.54 & $7.25 a$ & $6.75 a$ & 7.00 & $15.35 b$ & $11.80 \mathrm{~b}$ & 13.58 & $700.9 \mathrm{a}$ & 793.85 & 747.38 \\
\hline $\bar{x}$ & 0.4427 & 0.30 & - & 0.4307 & 0.32 & - & 0.94 & 0.61 & - & 35.50 & 12.77 & - \\
\hline C.V. (\%) & 5.07 & 3.47 & - & 15.31 & 11.69 & - & 10.15 & 7.65 & - & 11.31 & 3.55 & - \\
\hline Sig. & ** & * & - & ** & * & - & $* * *$ & * & - & *** & $*$ & - \\
\hline
\end{tabular}

Table 04. Seed germination (\%), accelerated ageing germination (\%) and field emergence (\%) of kenaf seed as influenced by drying period and method of threshing

\begin{tabular}{c|c|c|c|c|c|c|ccc|c}
\hline $\begin{array}{c}\text { Drying } \\
\text { period } \\
\times \\
\begin{array}{c}\text { Threshing } \\
\text { method }\end{array}\end{array}$ & \multicolumn{9}{|c|}{ Germination (\%) } & \multicolumn{3}{c}{$\begin{array}{c}\text { Accelerated ageing } \\
\text { germination (\%) }\end{array}$} & \multicolumn{3}{c}{ Field emergence (\%) } \\
\hline & 2014 & 2015 & Pooled & 2014 & 2015 & Pooled & 2014 & 2015 & Pooled \\
\hline $\mathrm{D}_{0} \times \mathrm{M}_{\mathrm{t}}$ & 86.00 & $89.75 \mathrm{ab}$ & 87.88 & $70.50 \mathrm{a}$ & $71.25 \mathrm{ab}$ & 70.88 & $83.50 \mathrm{a}$ & $83.75 \mathrm{ab}$ & 83.63 \\
$\mathrm{D}_{0} \times \mathrm{M}_{\mathrm{m}}$ & 86.25 & $90.00 \mathrm{a}$ & 88.13 & $70.25 \mathrm{a}$ & $72.00 \mathrm{a}$ & 71.13 & $82.50 \mathrm{ab}$ & $84.00 \mathrm{a}$ & 83.25 \\
$\mathrm{D}_{1} \times \mathrm{M}_{\mathrm{t}}$ & 85.00 & $86.50 \mathrm{abc}$ & 85.75 & $69.25 \mathrm{ab}$ & $69.75 \mathrm{ab}$ & 69.5 & $81.50 \mathrm{ab}$ & $81.25 \mathrm{c}$ & 81.38 \\
$\mathrm{D}_{1} \times \mathrm{M}_{\mathrm{m}}$ & 85.75 & $86.75 \mathrm{abc}$ & 86.25 & $69.75 \mathrm{ab}$ & $70.50 \mathrm{ab}$ & 70.13 & $81.25 \mathrm{ab}$ & $82.00 \mathrm{bc}$ & 81.63 \\
$\mathrm{D}_{2} \times \mathrm{M}_{\mathrm{t}}$ & 84.00 & $85.25 \mathrm{c}$ & 84.63 & $67.00 \mathrm{~b}$ & $68.25 \mathrm{~b}$ & 67.63 & $80.50 \mathrm{~b}$ & $80.25 \mathrm{c}$ & 80.38 \\
$\mathrm{D}_{2} \times \mathrm{M}_{\mathrm{m}}$ & 84.25 & $86.00 \mathrm{bc}$ & 85.13 & $68.50 \mathrm{ab}$ & $69.00 \mathrm{ab}$ & 68.75 & $80.25 \mathrm{~b}$ & $81.00 \mathrm{c}$ & 80.63 \\
\hline$S \bar{x}$ & 1.10 & 1.20 & - & 0.91 & 1.07 & - & 0.81 & 0.63 & - \\
C.V. $(\%)$ & 2.57 & 2.74 & - & 2.64 & 3.04 & - & 1.99 & 1.52 & - \\
L.Sig. & $N S$ & $*$ & - & $*$ & $*$ & - & $*$ & $*$ & - \\
\hline
\end{tabular}


C.V.= Coefficient of variation, ${ }^{*}, * *, * * *=$ Significant at $5 \%, 1 \%$ and $0.1 \%$ level, NS $=$ Not significant

In a column, figures having similar letter(s) do not differ significantly at $5 \%$ level as per DMRT

$\mathrm{D}_{0}=$ threshing without drying of harvested plant, $\mathrm{D}_{1}=$ threshing after 7 days drying of harvested plant, and $\mathrm{D}_{2}=$ threshing

after 7 days drying of harvested plant, $\mathrm{M}_{\mathrm{t}}=$ Traditional method of threshing and $\mathrm{M}_{\mathrm{m}}=$ Mechanical method of threshing.

\section{Conclusion}

Highest kenaf seed was obtained from mechanical method of threshing in all the drying period and minimum requirement of time. The best quality seed was also obtained at threshing without drying of harvested plant in both thethreshing methods.

\section{References}

[1]. Dauda, A. \& Aviara, A. N. (2001). Effect of threshing methods on maize grain damage and viability. AMA, Agricultural Mechanization in Asia, Africa and Latin America, 32(4), 43-46.

[2]. Deb, U. \& Bairagi, S. K. (2008). CPD (Central for Policy Dialogue), Profitability and Marketing of Jute in Bangladesh, Presentation at International Conference on Prospect of Jute and Kenaf as Natural Fibre, Dhaka, Bangladesh, 08-09, Feb 2008.

[3]. Gomez, K. A. \& Gomez., A. A. (1984). Statistical procedures for Agricultural Research 2nd Edn. John Willy and Sons., New York. pp. 97-111.

[4]. Henning A. Krzyzanowski, Francisco C. França Neto, José B. \& P. Costa Nilton. (2006). Technologies that add value to soybean seed. Seed News, The International Seed Magazine.

[5]. ISTA (1999). International rules for seed testing. International Seed Testing Association, Switzerland. Publication 24, pp. 155-202.

[6]. Jha, R. K., Saini, S. L. \& Ram, C. (1996). Effect of threshing methods on yield and mechanical damage in soybean. Crop Research, Hisar, 11(2), 248-250.

[7]. Kammar, C. \& Batagurki, S. B. (2001). Evaluation of different threshing methods for primary processing of finger millet. Mysore Journal of Agricultural Sciences, 35(2), 128-132.

[8]. Khan, M. A., Tareq, M. Z. \& Debnath, M. R. (2014). Effects of sowing time and variety on kenaf (Hibiscus cannabinus L.) seed production. Bangladesh J. Seed Sci. \& Tech. 18 (1\&2), 15-18.

[9]. Khan, M. K., Rayaguru, K., Panda, M. K. \& Bakhara, C. K., (1997). Effects of four stacking periods and threshing methods on paddy quality. AMA, Agricultural Mechanization in Asia, Africa and Latin America, 30(3), 45-50.

[10]. Lee Sun Ho, Cho, N., Hong, J., Lee, W., Choi, H. E. \& Kang, C. (1998). Development of sesame thresher. RDA Journal of Farm Management and Agricultural Engineering, 40(1), 44-48.

[11]. Mostofa, M. G. (2012). Genetic divergence combining ability, heterosis and gene action for yield characters in kenaf (H. cannabinus). PhD thesis, Dept. of Genet. \& Pl. Breed., Bangladesh Agricultural University, Mymensingh, Bangladesh.

[12]. Vishwanatha, B. T. (2005). An economic analysis of threshing of maize crop in Karnataka: A comparative study of mechanical v/s traditional methods. MS thesis, Dept. of Agricultural Economics, University of Agricultural Science, Dharwad.

\section{HOW TO CITE THIS ARTICLE?}

\section{APA (American Psychological Association)}

Mollah, A. F., Khan, M. A., Tareq, M. Z., Hoque, A. B. M. Z. and Debnath, M. R. (2016). Effect of drying period of harvested plant and method of threshing on yield and quality of kenaf seed. Journal of Bioscience and Agriculture Research, 11(02), 947-952.

\section{MLA (Modern Language Association)}

Mollah, A. F., Khan, M. A., Tareq, M. Z., Hoque, A. B. M. Z. and Debnath, M. R. "Effect of drying period of harvested plant and method of threshing on yield and quality of kenaf seed". Journal of Bioscience and Agriculture Research, 11.02(2016): 963-967.

\section{Chicago and or Turabian}

Mollah, A. F., Khan, M. A., Tareq, M. Z., Hoque, A. B. M. Z. and Debnath, M. R. "Effect of drying period of harvested plant and method of threshing on yield and quality of kenaf seed". Journal of Bioscience and Agriculture Research, 11 no.02(2016): 963-967. 